\title{
Peningkatan Kemampuan Penulisan Karya Ilmiah Internasional Bereputasi dengan Faktor Dampak yang Tinggi
}

\author{
Saprizal Hadisaputra ${ }^{1 *}$, Gunawan ${ }^{1}$, Ilham Syahrul Jiwandono ${ }^{1}$ \\ ${ }^{1}$ Program Studi Pendidikan Kimia, Jurusan Pendidikan MIPA, Fakultas Keguruan dan Ilmu Pendidikan, Universitas Mataram, Indonesia \\ ${ }^{2}$ Program Studi Pendidikan Fisika, Jurusan Pendidikan MIPA, Fakultas Keguruan dan Ilmu Pendidikan, Universitas Mataram, Indonesia \\ ${ }^{3}$ Program Pendidikan Guru Sekolah Dasar, Jurusan Ilmu Pendidikan, Fakultas Keguruan dan Ilmu Pendidikan, Universitas Mataram, \\ Indonesia
}

\section{Article Info}

Received: November $14^{\text {th }}, 2020$

Revised: December 17th, 2020

Accepted: December $21^{\text {th }}, 2020$

\begin{abstract}
Abstrak: Dosen harus memiliki kemampuan untuk melakukan penelitian dan penulisan karya ilmiah. Ini menjadi hal yang sangat penting baik demi kepentingan dirinya sendiri maupun kepentingan Perguruan Tinggi. Namun, sebagian besar dosen terkendala dalam hal penulisan karya ilmiah karena harus melalui proses yang rumit dan membutuhkan kemampuan penulisan karya ilmiah yang baik. Kendala tersebut membuat dosen menjadi terhambat untuk memenuhi persyaratan kenaikan pangkatnya, dan juga menyebabkan stagnasi pada peningkatan kompetensi di bidang penelitian dan pengembangan karya ilmiah. Permasalahan ini juga terjadi di Fakultas Keguruan dan Ilmu Pendidikan (FKIP) Universitas Mataram. Berdasarkan data Sinta tahun 2019, jumlah total publikasi artikel terindeks scopus dari dosen-dosen FKIP Universitas Mataram selama 10 tahun hanya rata rata $4 \%$ dari total jumlah dosen yang publikasi pada jurnal atau seminar internasional terindeks pada pengindeks. Jumlah publikasi internasional ini masih rendah. Berdasarkan hal tersebut, maka FKIP Universitas Mataram melalui Badan Penelitian dan Pengabdian Pada Masyarakat Fakultas BP3MF melaksanakan pelatihan penulisan artikel dan teknik publikasi di Jurnal Internasional dengan tujuan untuk meningkatkan kualitas dan kuantitas penelitian dan pengabdian kepada masyarakat yang dilakukan oleh dosen. Hal ini menjadi sangat diperlukan untuk dapat meningkatkan kemampuan dosen di bidang penelitian dan pengembangan karya ilmiah di FKIP Universitas Mataram. Metode yang akan dipakai pada kegiatan pengabdian masyarakat ini adalah Focus Group Discussion (FGD) berupa pelatihan dan pendampingan peningkatan kemampuan dosen menulis ilmiah. Kegiatan akan dilaksanakan dalam tiga tahap yaitu: (1) tahap perencanaan, (2) tahap observasi, (3) tahap pelaksanaan, (4) tahap evaluasi. Pengabdian menyajikan materi, ceramah, dan diskusi dalam menyampaikan materi yang terdiri dari: penulisan artikel, kerangka penulisan ilmiah dosen, teknik publikasi jurnal internasional dan pemanfaat tool untuk alih bahasa. Luaran kegiatan ini adalah peserta memperoleh pengetahuan penting tentang meningkatkan keterampilan menulis ilmiah mereka. Selain itu, peserta juga memperoleh wawasan yang lebih luas mengenai prosedur publikasi jurnal di tingkat internasional.
\end{abstract}

Kata Kunci: publikasi; jurnal; internasional; pelatihan.

Abstract: Lecturers must have the ability to conduct research and write scientific papers. This is very important both for the sake of itself and the interests of the Higher Education. However, most lecturers are constrained in terms of writing scientific papers because they have to go through a complicated process and require good scientific writing skills. These obstacles hampered lecturers from fulfilling the requirements for promotion, and also led to stagnation in increasing competence in the field of research and development of scientific works. This problem also occurs in the Teacher Training and Education Faculty (FKIP), Mataram University. Based on Sinta's data in 2019, the total number of scopus indexed article publications from FKIP Mataram University lecturers for 10 years was only an average of $4 \%$ of the total number of lecturers who published in international journals or seminars indexed on the indexer. The number of international publications is still low. Based on this, the FKIP Mataram University through the BP3MF Faculty of Research and Community Service Agency conducted training on article writing and publication techniques in international journals with the aim of improving the quality and quantity of research and community service carried out by lecturers. This is very necessary in order to improve the ability of lecturers in the field of research and development of scientific work at the FKIP, Mataram University. The method that will be used in this community service activity is Focus Group Discussion (FGD) in the form of training and mentoring to improve the ability of lecturers to write scientifically. The activity will be carried out in three stages, namely: (1) the planning stage, (2) the observation stage, (3) the implementation stage, (4) the evaluation stage. The service activity presents material, lectures, and discussions in delivering material consisting of: article writing, 
lecturer scientific writing framework, international journal publication techniques and the use of tools for language translation. The output of this activity is that participants gain important knowledge about improving their scientific writing skills. In addition, participants also gained broader insight into journal publication procedures at the international level.

Keywords: publication; journal; international; training.

Citation: Hadisaputra, S., Gunawan., \& Jiwandono, I.S. (2020). Pengabdian pada Masyarakat: Peningkatan Kemampuan Penulisan Karya Ilmiah Internasional Bereputasi dengan Faktor Dampak yang Tinggi. Unram Journal of Community Service 1(1), 6-11.

\section{Pendahuluan}

Undang-undang Guru dan Dosen menekankan bahwa kemampuan untuk melaksanakan penelitian dan mengembangkan karya ilmiah merupakan salah satu syarat kompetensi utama yang harus dimiliki oleh dosen. Keahlian, kemahiran, serta kecakapan harus dimiliki dosen dalam melakukan penelitian yang bermuara pada karya ilmiah yang berkualitas. Jika dosen lemah dalam hal ini maka akan berdampak pada rendahnya kualitas karya ilmiah yang dihasilkannya. Dengan demikian, dosen harus memiliki kemampuan untuk melakukan penelitian dan penulisan karya ilmiah demi untuk kepentingan dirinya sendiri dan kepentingan peningkatan kualitas pendidikan di tingkat perguruan tinggi (Amaliyah, 2019; Mulyani, 2017, Cahyana, 2010).

Publikasi internasional memiliki manfaat antara lain pertama, dapat meningkatkan kualifikasi dan reputasi dosen dan perguruan tinggi tempat dosen tersebut mengajar; kedua, dapat melebarkan kesempatan bekerjasama dengan peneliti seluruh dunia; ketiga, memiliki kesempatan memperoleh basiswa sekolah atau penghargaan bidang ilmu pengetahuan; keempat dapat dijadikan syarat lulus program pascasarjana; kelima, memiliki kontribusi pada pengembangan riset dan Pendidikan nasional; keenam, memiliki kesempatan mengangkat kearifan local ke tingkatan internasional (Salam, 2017; Gunawan, 2019; Firmansyah, 2020). Berdasarkan beragam manfaat di atas, maka sangat disarankan bagi para dosen untuk berupaya menulis dan menerbitkan jurnal internasional. Namun demikian, dalam praktiknya terdapat kendala-kendala yang dialami dosen untuk merealisasikan hal tersebut. Sebagian besar dosen terkendala dalam hal penulisan karya ilmiah karena harus melalui proses yang rumit dan membutuhkan kemampuan penulisan karya ilmiah yang baik (Rahim, 2020; Retnowati, 2018; Husin, 2020; Rohmah, 2016). Kendala tersebut membuat dosen menjadi terhambat untuk memenuhi persyaratan kenaikan pangkatnya, dan juga menyebabkan stagnasi pada peningkatan kompetensi di bidang penelitian dan pengembangan karya ilmiah.

Permasalahan yang sama dapat ditemukan di
FKIP Universitas Mataram. Berdasarkan data Sinta Universitas Mataram (diakses bulan maret 2020) jumlah total publikasi artikel terindeks scopus dari dosen- dosen FKIP Universitas Mataram selama 10 tahun terkakhir adalah berjumlah 120 artikel, sedangkan jumlah dosen mencapai 265 orang. Hal ini berarti hanya rata rata $4 \%$ dari total jumlah dosen yang publikasi pada jurnal atau seminar internasional terindeks pada pengindeks yang bereputasi selama 10 tahun terakhir. Jumlah publikasi ini masih sangat rendah. Selanjutnya, bahkan terdapat 3 program studi yang dosennya tidak pernah publikasi pada jurnal maupun prosiding seminar internasional terindeks pada pengindeks yang bereputasi.

Berdasarkan hal tersebut, maka Fakultas KIP Universitas Mataram melalui Badan Penelitian dan Pengabdian Pada Masyarakat Fakultas BP3MF akan melaksanakan pelatihan penulisan artikel dan teknik publikasi di Jurnal Internasional dengan tujuan untukmeningkatkan kualitas dan kuantitas penelitian dan pengabdian kepada masyarakat yang dilakukan oleh dosen. Hal ini menjadi sangat diperlukan untuk dapat meningkatkan kemampuan dosen di bidang penelitian dan pengembangan karya ilmiah di FKIP Universitas Mataram. Secara lebih spesifik, pelatihan tersebut perlu dilakukan sebagai bagian dari upaya untuk mendorong dosen dalam memenuhi beban kerjanya terkait bidang penelitian, memenuhi persyaratan kenaikan pangkat dosen, memenuhi kelayakan profesi dosen, dan untuk meningkatkan kesejahteraan dosen.

Menurut fenomena yang umum terjadi berkaitan dengan permasalahan yang dihadapi dosen pada bidang penelitian dan pengembangan karya ilmiah, serta hasil analisis situasi di lingkungan dosen Fakultas Keguruan dan Ilmu Pendidikan Universitas Mataram, maka dapat diidentifikasi beberapa permasalahan mendasar yang mendorong perlunya dilakukan pelatihan penulisan artikel dan teknik publikasi di Jurnal Internasional sebagai berikut: (1) kemampuan penulisan karya ilmiah sebagian dosen yang masih belum mencukupi untuk menulis jurnal dengan standar internasional; (2) masih terbatasnya kemampuan dosen terkait tata cara mempublikasikan jurnal pada penerbit jurnal internasional; dan (3) 
terbatasnya forum ilmiah yang dapat meningkatkan motivasi, pengetahuan dan kemampuan dosen di bidang penulisan dan publikasi karya ilmiah Berdasarkan beberapa permasalahan tersebut, maka pelaksanaan pelatihan penulisan dan teknik publikasi jurnal internasional oleh BP3MF FKIP Universitas Mataram diharapkan dapat meningkatkan kompetensi dosen-dosen Universitas Mataram dalam bidang penelitian dan pengembangan karya ilmiah, yang disamping diperlukan untuk memenuhi beban kerja dan jabatan profesi dosen, juga dapat meningkatkan kualitas pendidikan.

Berdasarkan permasalahan di atas maka solusi yang ditawarkan pada kegiatan pengabdian masyarakat ini adalah memberikan pelatihan dan kegiatan pendampingan. Tahapan Pelatihan dan pendampingan meliputi: Pelatihan dan Pendampingan mengenai tahapan persiapan penulisan artikel dan teknik mendapatkan literatur primer; Pelatihan dan Pendampingan teknik publikasi jurnal internasional, termasuk mulai dari persiapan naskah, submit, cara menjawab komentar para reviewer, menjawab proofread dan penerbitan artikel. Pelatihan cara mencari jurnal internasional yang tepat ditambahkan cara cek plagiarism atau similarity.

\section{Metode Pelaksanaan}

Metode pelaksanaan program pengabdian kepada masyarakat ini adalah pelatihan dan pendampingan Peningkatan Kemampuan Penulisan Karya Ilmiah Dan Teknik Publikasi Di Jurnal Internasional Bagi Dosen FKIP Universitas Mataram. Kegiatan akan dilaksanakan dalam tiga tahap yaitu: (1) Tahap perencanaan dan observasi, (2) Tahap pelaksanaan, (3) Tahap evaluasi. Kegiatan pelatihan penulisan artikel dan teknik publikasi di jurnal internasional yang diselenggarakan oleh Fakultas KIP Universitas Mataram dan BP3MF merupakan salah satu bentuk Program Kemitraan Masyarakat (PKM) dengan sasaran untuk meningkatkan kemampuan para dosendosen di Universitas Mataram dalam menyusun karya ilmiah yang memenuhi standar penerbitan bertaraf internasional. PKM ini dilaksanakan sebagai bentuk tindak lanjut atas permasalahan yang dihadapi dosen, khususnya di Universitas Mataram, terkait dukungan dan motivasi dalam pengembangan karya ilmiah yang berkualitas dan tata cara penerbitan karya ilmiah tersebut di jurnal internasional.

PKM dilaksanakan melalui metode ceramah dan presentasi, serta dilengkapi dengan pemberian tugas mandiri yang akan dievaluasi hasilnya pada akhir kegiatan. Dengan demikian, diharapkan para dosen peserta kegiatan dapat memiliki peningkatan yang signifikan dalam hal kemampuan menulis karya ilimah berkualitas internasional, serta mampu mengetahui cara-cara untuk mempublikasikan karya ilmiahnya pada penerbit jurnal internasional. Prosedur Pelaksanaan Pelatihan 1. Tahap Persiapan Kegiatan PKM dimulai dari tahap persiapan yang mencakup pembuatan dan pengajuan rencana kegiatan. Pembuatan rencana kegiatan mengacu pada kebutuhan pelatihan penulisan karya ilmiah dan teknik publikasi di jurnal internasional dan pengetahuan dari pemateri atas topik pelatihan tersebut. Setelah seluruh topik bahasan disampaikan, selanjutnya terdapat sesi tugas mandiri dan evaluasi. Sesi tugas mandiri merupakan sesi dimana peserta pelatihan diinstruksikan untuk menyusun karya ilmiah selama waktu yang ditentukan sesuai dengan materi yang telah diterima. Setelah tugas mandiri selesai, selanjutnya terdapat sesi evaluasi untuk mengetahui hasil penulisan karya ilmiah dari para peserta dan saran-saran perbaikan jika diperlukan.

\section{Hasil dan Pembahasan}

\section{Tahapan Persiapan Kegiatan}

Tahap Persiapan Kegiatan PKM dimulai dari tahap persiapan yang mencakup pembuatan dan pengajuan rencana kegiatan. Pembuatan rencana kegiatan mengacu pada kebutuhan pelatihan penulisan karya ilmiah dan teknik publikasi di jurnal internasional dan pengetahuan dari pemateri atas topik pelatihan tersebut. Setelah disepakati tema, narasumber dan waktu kegiatan maka disusun informasi penyebaran kegiatan. Leaflet kegiatan pengabdian dapat dilihat pada Gambar 1.

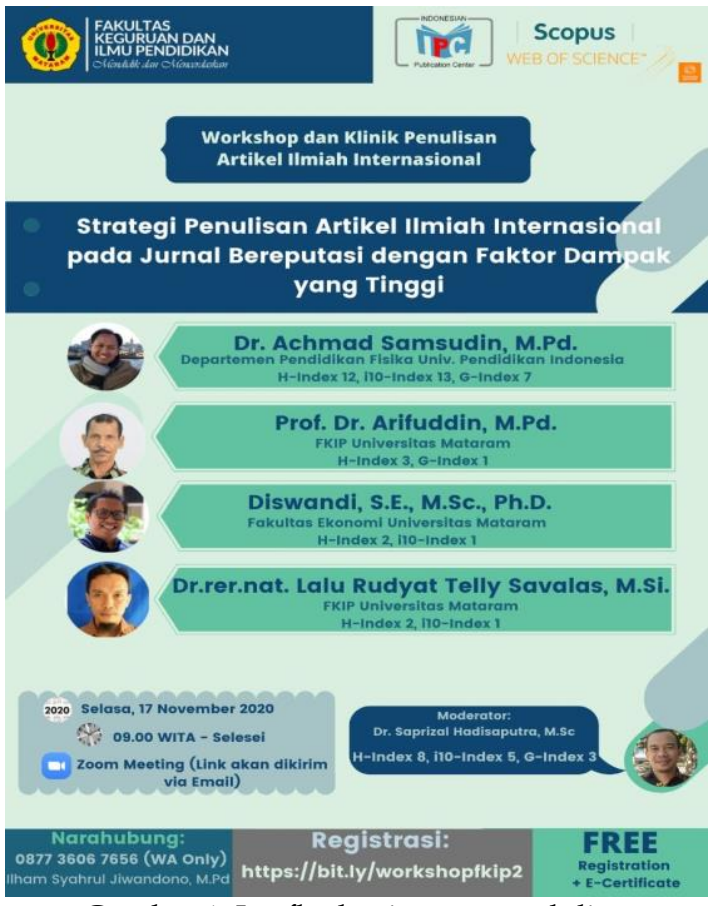

Gambar 1. Leaflet kegiatan pengabdian 


\section{Tahap Pelaksanaan Kegiatan PKM}

Kegiatan PKM dilaksanakan pada selasa, 17 september 2020. Foto-foto kegiatan dapat dilihat pada Gambar 2. Sesuai dengan topik bahasan yang telah ditentukan, maka dilakukan pembagian waktu sesuai dengan kebutuhan pembahasan tiap topik. Secara berurutan sesuai dengan alokasi waktu yang telah ditetapkan. Penyampaian materi-materi tersebut dilakukan dengan beberapa metode, mulai dari ceramah, presentasi, hingga diskusi dan interaksi timbal balik yang memungkinkan peserta PKM mengajukan pertanyaan dan saling menanggapi pertanyaan dari peserta lainnya. Materi pertama yang disampaikan adalah tentang penulisan artikel yang mencakup bahasan mengenai alasan untuk menulis artikel, cara menentukan topik penelitian. Materi pertama juga mencakup bahasan mengenai cara mempersiapkan artikel jurnal ilmiah internasional termasuk memilih jurnal ilmiah target. Materi ini disampaikan oleh Dr. Achmad Samsudin, M.Pd dari Universitas Pendidikan Indonesia. Materi terkait teknis dari persiapan draft atau manuscript karya ilmiah hingga diterbitkan sebagai artikel yang telah siap edar. Inti dari penulisan akademis adalah penggunaan kembali: membangun ide, kata-kata dan bahasa orang lain. Tidak mungkin bagi sarjana pemula untuk menulis secara memadai tanpa terlebih dahulu merasa nyaman dengan menggunakan kembali literatur penelitian. Belajar dari artikel penelitian di jurnal target. Setelah membangun perpustakaan literatur penelitian mereka, peneliti kemudian dapat belajar bagaimana menganalisis bahasa artikel yang diterbitkan dalam jurnal target mereka, yang bertentangan dengan isinya. Cobalah untuk memahami konstruksi teks: jangan tanya apa yang penulis katakan; periksa bagaimana mereka mengatakannya. Peneliti harus melihat 'tahapan' argumen yang dibuat oleh penulis lain melalui struktur dan format kalimat tertentu, yang dapat didaur ulang.

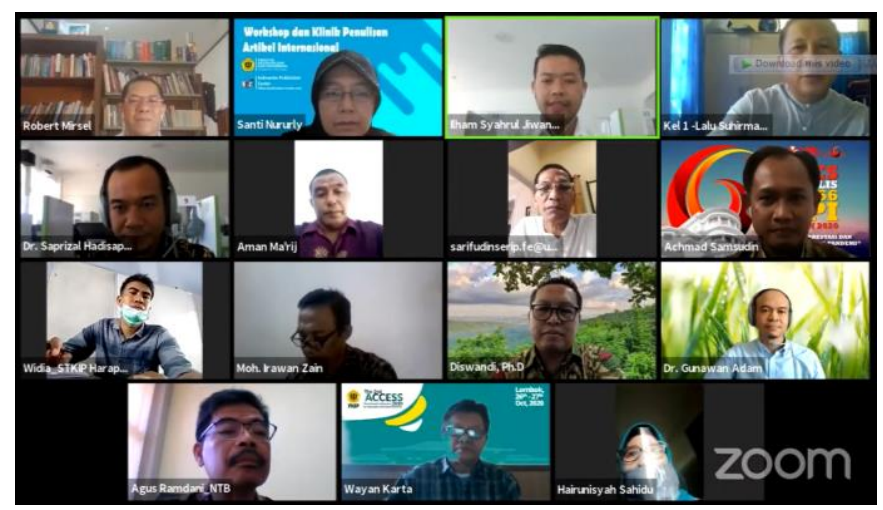

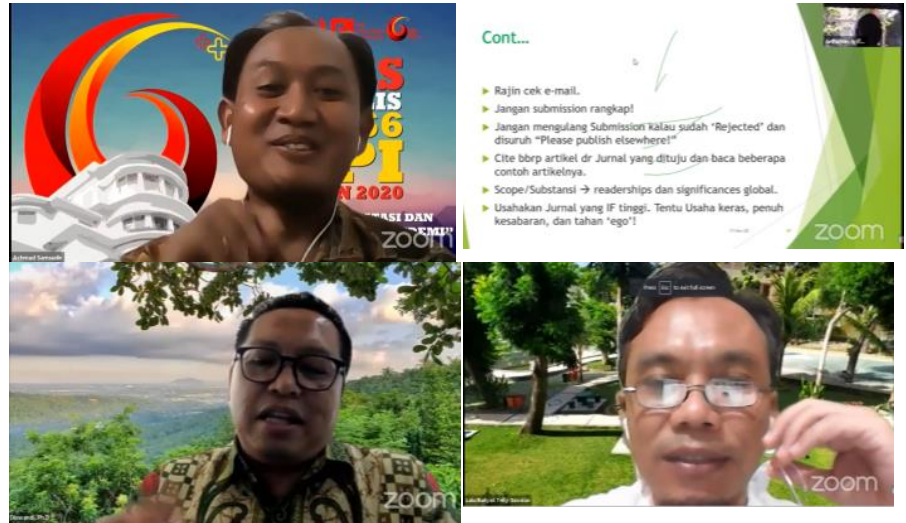

Gambar 2: Foto foto kegiatan Pengabdian

\section{Tahap Pelaksanaan Kegiatan PKM}

Kegiatan PKM dilaksanakan pada selasa, 17 september 2020. Foto-foto kegiatan dapat dilihat pada Gambar 1b. Sesuai dengan topik bahasan yang telah ditentukan, maka dilakukan pembagian waktu sesuai dengan kebutuhan pembahasan tiap topik. Secara berurutan sesuai dengan alokasi waktu yang telah ditetapkan. Penyampaian materi-materi tersebut dilakukan dengan beberapa metode, mulai dari ceramah, presentasi, hingga diskusi dan interaksi timbal balik yang memungkinkan peserta PKM mengajukan pertanyaan dan saling menanggapi pertanyaan dari peserta lainnya. Materi pertama yang disampaikan adalah tentang penulisan artikel yang mencakup bahasan mengenai alasan untuk menulis artikel, cara menentukan topik penelitian. Materi pertama juga mencakup bahasan mengenai cara mempersiapkan artikel jurnal ilmiah internasional termasuk memilih jurnal ilmiah target. Materi ini disampaikan oleh Dr. Achmad Samsudin, M.Pd dari Universitas Pendidikan Indonesia. Materi terkait teknis dari persiapan draft atau manuscript karya ilmiah hingga diterbitkan sebagai artikel yang telah siap edar. Inti dari penulisan akademis adalah penggunaan kembali: membangun ide, kata-kata dan bahasa orang lain. Tidak mungkin bagi sarjana pemula untuk menulis secara memadai tanpa terlebih dahulu merasa nyaman dengan menggunakan kembali literatur penelitian. Belajar dari artikel penelitian di jurnal target. Setelah membangun perpustakaan literatur penelitian mereka, peneliti kemudian dapat belajar bagaimana menganalisis bahasa artikel yang diterbitkan dalam jurnal target mereka, yang bertentangan dengan isinya. Cobalah untuk memahami konstruksi teks: jangan tanya apa yang penulis katakan; periksa bagaimana mereka mengatakannya. Peneliti harus melihat 'tahapan' argumen yang dibuat oleh penulis lain melalui struktur dan format kalimat tertentu, yang dapat didaur ulang.

Materi kedua adalah tentang sudut pandang reviewer dan editor jurnal Internasional mengenai 
kelayakan suatu artikel ilmiah untuk diterbitkan di jurnal target. Materi ini disampiakan oleh Dr. Diswandi. Memilih jurnal yang tepat untuk penelitian Anda. Mengirimkan makalah ke jurnal yang tidak sesuai adalah penyebab utama penolakan artikel. Saat memilih jurnal, luangkan waktu untuk meninjau tujuan dan cakupan jurnal untuk memastikan kesesuaiannya dengan manuskrip Anda. Bagian dan pertanyaan di bawah ini akan membantu Anda membuat pilihan terbaik saat memutuskan di mana akan mempublikasikan penelitian Anda. Apakah jurnal mencakup berbagai topik atau lebih terfokus? Untuk jurnal subjek khusus, hanya manuskrip relevan yang akan dipertimbangkan untuk publikasi. Jika artikel Anda lintas disiplin atau mencakup banyak topik, jurnal dengan cakupan yang lebih luas akan lebih cocok untuk publikasi artikel Anda. Anda dapat dengan mudah menemukan tujuan dan cakupan jurnal kami di situs web mereka dan ini akan memberi Anda pemahaman yang jelas tentang jenis penelitian yang akan dipertimbangkan. Jenis konten apa yang telah diterbitkan jurnal sebelumnya? Sebagai pembaca, apakah Anda berharap untuk melihat artikel Anda bersama dengan artikel yang sudah ada? Apakah itu artikel yang mungkin pernah Anda baca selama penelitian Anda? Ada baiknya juga untuk memeriksa apakah sebuah jurnal menerbitkan Isu Khusus yang relevan dengan bidang penelitian Anda - kumpulan artikel yang ditargetkan, tepat waktu, dan berwawasan ini dapat memberikan indikasi yang sangat baik tentang jenis konten yang diterbitkan jurnal.

Materi ketiga disampaikan oleh Prof Ariffuddin dari FKIP Universitas Mataram menyampaikan pemilihan diksi kata dan kalimat yang tepat untuk artikel agar Bahasa jurnal terkesan tidak monoton. Mempersiapkan naskah Anda. Tulis draf makalah dalam bahasa Inggris apa pun yang dimiliki - ini jauh lebih mudah daripada menulisnya dalam bahasa Anda sendiri dan kemudian menerjemahkannya. Jangan terlalu khawatir tentang tata bahasa dan ejaan pada tahap ini. Sangat membantu untuk melihat saluran publikasi target Anda dan orang lain di bidang yang sama, untuk mengambil tip tentang frase, nuansa, bahasa Inggris. Anda mungkin membutuhkan lebih banyak bantuan 'langsung' di sini, jadi carilah seseorang yang dapat membantu Anda mengekspresikan diri Anda dengan lebih jelas dalam bahasa Inggris. Ini tidak sama dengan menggunakan layanan pengeditan profesional (lihat di bawah). Mintalah bantuan dari kolega yang bahasa Inggrisnya lebih baik daripada bahasa Inggris Anda, sehingga mereka dapat membantu Anda menjelaskan maksud Anda. Setelah Anda mendapatkan indikasi minat dari jurnal tersebut, inilah saatnya untuk fokus pada peningkatan bahasa. Jika Anda tidak memiliki kolega yang dapat membantu, Anda dapat menyewa editor bahasa profesional. Ini mengkhususkan diri dalam membantu penulis mengekspresikan diri mereka dalam bahasa Inggris yang jelas.

Materi keempat disampiakan oleg Dr.rer.nat Lalu Rudyat Telly Savalas adalah Beberapa kesalahan yang sangat umum dilakukan penulis saat menulis makalah jurnal: 1 . Menulis abstrak yang secara stylistis bukan sebuah abstrak. Abstrak mengikuti aturan tertentu. Abstrak bukanlah ringkasan singkat dari apa yang anda lakukan. Abstrak bukanlah latar belakang pekerjaan anda; 2. Jangan berasumsi bahwa pembaca anda mengetahui pentingnya topik yang anda pelajari. Saat anda memperkenalkan pekerjaan anda (di bagian pendahuluan), anda perlu membahas tantangan utama mana yang menjadi fokus pekerjaan anda. 3. Bingungkan bibliografi dengan tinjauan literatur. Serius, tinjauan pustaka meninjau literatur - seperti yang disebutkan namanya. Harus ada analisis literatur. Apa yang terjadi secara kronologis di bidang anda? Siapa yang setuju dan siapa yang tidak setuju? Bisakah anda meringkas informasi dalam tabel ikhtisar? Anda perlu menganalisis literatur untuk menulis tinjauan literatur. 4. Mengikuti struktur laporan tesis atau penelitian, Sebuah laporan penelitian melaporkan eksperimen atau pekerjaan lain yang telah dilakukan. Makalah jurnal melangkah lebih jauh: anda perlu membingkai pekerjaan anda dalam tubuh pengetahuan saat ini, mendiskusikan hasil anda secara kritis, 5. Tidak menyediakan pembahasan lebih dalam. 6 . Menempatkan informasi baru di bagian ringkasan. 7 . Menggunakan referensi tidak lengkap dan kacau (Ginanjar, 2018). 8. Mengirim tanpa data pembuktian yang layak.

\section{Hambatan}

Pelaksanaan kegiatan PKM untuk meningkatkan kemampuan penulisan karya ilmiah dan pemahaman teknik publikasi di jurnal internasional ini dapat dikatakan berjalan dengan lancar dan mencapai hasil yang diharapkan. Namun demikian, terdapat beberapa hambatan yang dialami selama proses pelaksanaan kegiatan PKM. Hambatan pertama adalah terkait dengan durasi kegiatan PKM yang sangat terbatas mengingat target yang ingin dicapai dari kegiatan tersebut. Oleh karena itu, penyampaian materi disampaikan dengan tanpa dapat memastikan bahwa seluruh peserta benar-benar memahami keseluruhan materi tersebut. Selain itu, praktik penyusunan karya ilmiah dalam sesi tes mandiri juga dirasa sangat singkat waktunya, sehingga tidak dapat mendorong peserta untuk mempraktikkan seluruh pengetahuan yang diperoleh selama kegiatan PKM 


\section{Kesimpulan}

Kegiatan PKM yang diselenggarakan oleh BP3MF Fakultas Keguruan dan Ilmu Pendidikan Universitas Mataram tujuan untuk meningkatkan kemampuan penulisan karya ilmiah dan pemahaman mengenai teknik publikasi di jurnal internasional. Secara keseluruhan, kegiatan tersebut dapat berlangsung dengan lancar dan disambut dengan antusias oleh seluruh peserta. Seluruh materi yang dipersiapkan panitia berhasil disampaikan oleh pemateri dalam waktu yang sesuai dengan alokasi waktu yang ditetapkan di awal kegiatan. Meskipun tiap sesi kegiatan dirasa terlalu singkat mengingat materi penulisan yang cukup sulit, namun para peserta merasa telah mendapatkan pengetahuan penting yang bermanfaat untuk meningkatkan kemampuan penulisan karya ilmiahnya. Selain itu, para peserta juga memperoleh wawasan lebih luas mengenai tata cara publikasi jurnal, baik di tingkat nasional maupun internasional. Tindak lanjut tersebut dapat berupa pelaksanaan kegiatan PKM dengan topik sejenis pada waktu-waktu mendatang secara periodik, atau dengan menetapkan target penulisan karya ilmiah individual bagi para dosen.

\section{Ucapan Terimakasih.}

Terimakasih atas dukungan pendanaan PNBP tahun 2020 dari FKIP Universitas Mataram dengan nomor kontrak: 1999/UN18/LPPM/2020

\section{Daftar Pustaka}

Amaliyah, A. (2019). Program Kemitraan Masyarakat: Peningkatan Kemampuan Penulisan Karya Ilmiah dan Teknik Publikasi di Jurnal Internasional. Intervensi Komunitas, 1(1), 48-56.

Firmansyah, A., Qadri, R. A., \& Arham, A. (2020). Pelatihan melalui Web Seminar terkait Publikasi Artikel untuk Menembus Jurnal Sinta 2 dan Scopus. Abdimas: Jurnal Pengabdian Masyarakat Universitas Merdeka Malang, 5(2), 131-138.

Ginanjar, A. (2018). Peningkatan Mutu Karya Tulis Dosen FIS Dengan Menggunakan Reference Manager Software Mendeley. Harmony, 3(2), 199203.

Gunawan, G., Jufri, A. W., Sedijani, P., Hadiprayitno, G., \& Bachtiar, I. (2019). Pelatihan Penulisan Pada Jurnal Internasional Bagi Dosen Dan Mahasiswa Magister Pendidikan IPA Unram. Jurnal Pendidikan dan Pengabdian Masyarakat, 2(4).

Husin, D. (2020, February). Penguasaan Instrument Artikel Bisnis dan Teknis Publikasi Ilmiah pada
Jurnal Bereputasi Internasional. In Prosiding Seminar Nasional Politeknik Negeri Lhokseumawe (Vol. 3, No. 1, p. 198).

Mulyani, F. (2017). Konsep Kompetensi Guru Dalam Undang-Undang Nomor 14 Tahun 2005 Tentang Guru Dan Dosen (Kajian Ilmu Pendidikan Islam). Jurnal Pendidikan UNIGA, 3(1), 1-8.

Rahmawati, C., Meliyana, M., Yuliana, Y., \& Zain, H. (2018). Pelatihan Software Mendeley Dalam Peningkatan Kualitas Artikel Ilmiah Bagi Dosen. Jurnal Pengabdian Kepada Masyarakat, 8(1), 30-36

Rahim, A., Malik, A., Hastuti, D. R. D., Syam, U., \& Sabar, W. (2020, November). Pelatihan Teknik Penulisan Artikel Ilmiah Internasional Bereputasi dan Nasional Terakreditasi Mahasiswa Program Pascasarjana Universitas Negeri Makassar. In Seminar Nasional Pengabdian Kepada Masyarakat (Vol. 1, No. 2).

Retnowati, T. H., Mardapi, D., \& Kartowagiran, B. (2018). Kinerja dosen di bidang penelitian dan publikasi ilmiah. Jurnal Akuntabilitas Manajemen Pendidikan, 6(2), 215-225.

Rohmah, N., AY, M. H., \& Kusmintardjo, K. (2016). Strategi peningkatan kemampuan dosen dalam penulisan karya ilmiah (studi multi kasus pada Unisda dan Staidra di Kabupaten Lamongan). Jurnal Pendidikan: Teori, Penelitian, Dan Pengembangan, 1(7), 1312-1322.

Salam, R., Akhyar, M., Tayeb, A. M., \& Niswaty, R. (2017). Peningkatan Kualitas Publikasi Ilmiah Mahasiswa dalam Menunjang Daya Saing Perguruan Tinggi. Jurnal Office, 3(1), 61-65. 